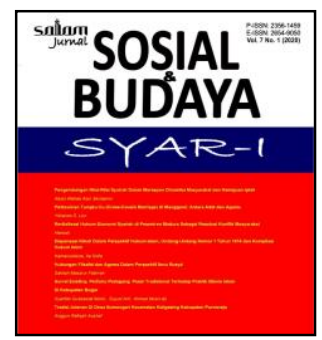

\title{
Itikad Baik Dalam Perjanjian Suatu Perspektif Hukum dan Keadilan*
}

\author{
Endang Suprapti ${ }^{1}$ Arihta Esther Iarigan ${ }^{2}$ \\ Universitas Tama Jagakarsa, Jakarta \\ do \\ $\underline{10.15408 / \mathrm{sjsbs} . v 8 \mathrm{i} 1.19377}$
}

\begin{abstract}
Contract or agreement is a first step in carrying out a fulfillment of needs and interests so humans are always in touch with each other in various places and times with various events. How good faith becomes the basis for parties to make an agreement. To answer this problem, research sources in the form of primary legal materials are needed, both in the form of laws and regulations, court decisions and secondary sources in the form of books, texts, legal dictionaries, legal journals. The research method in this paper uses primary and secondary legal materials, the law approach and conceptual approach. This type of research is normative and qualitative in nature.
\end{abstract}

Keywords: Good faith, Agreement, Justice

\begin{abstract}
Abstrak
Kontrak atau perjanjian adalah suatu langkah awal dalam menyelenggarakan suatu pemenuhan kebutuhan dan kepentingan maka manusia selalu berhubungan satu sama lain di berbagai tempat dan waktu dengan berbagai macam peristiwa. Bagaimana itikad baik menjadi dasar bagi pihak dalam membuat suatu perjanjian. Untuk menjawab permasalahan ini diperlukan sumber penelitian berupa bahan hukum primer, baik berupa peraturan perundang-undangan, putusan pengadilan dan sumber sekunder berupa buku-buku, teks, kamus-kamus hukum, jurnal hukum. Metode penelitian dalam penulisan ini menggunakan bahan hukum primer dan sekunder, pendekatan undang-undang dan pendekatan konseptual. Jenis Penelitian ini adalah Normatif dan bersifat kualitatif.
\end{abstract}

Kata Kunci: Itikad Baik, Perjanjian, Keadilan

\footnotetext{
* Received: January 16, 2021, Revision: January 20, 2021, Published: February 08, 2021.

${ }^{1}$ Endang Suprapti adalah Dosen Fakultas Hukum Universitas Tama Jagakarsa, Jakarta. E-mail: endangspt0@gmail.com.

${ }^{2}$ Arihta Esther Tarigan adalah Dosen Fakultas Hukum Universitas Tama Jagakarsa, Jakarta. Email: Arihtaesther@gmail.com.
} 


\section{A. PENDAHULUAN}

Kontrak atau perjanjian adalah suatu langkah awal dalam menyelenggarakan suatu pemenuhan kebutuhan dan kepentingan maka manusia selalu berhubungan satu sama lain di berbagai tempat dan waktu dengan berbagai macam peristiwa. Idealnya sebagaimana yang diharapkan dalam berinteraksi, perjanjian bersifat seimbang antara kedua belah pihak. Praktek di masyarakat sering terjadi perjanjian yang tidak seimbang mengabaikan prinsip-prinsip perjanjian.

Hukum diperlukan sebagai sarana untuk menyelesaikan suatu masalah yang timbul dalam proses interaksi tersebut (problem solving). Hukum sesungguhnya memiliki potensi yang cukup besar untuk melakukan perubahan yang direncanakan dalam suatu negara. Legalitas formal sebagai salah satu yang dimiliki, selain itu hukum juga mempunyai kewenangan pemaksa yang dalam bekerjanya didukung aktivitas birokrasi ${ }^{3}$ Dalam perspektif perlindungan konsumen hingga saat ini masih banyak kontrak-kontrak yang cenderung tidak adil. Meskipun sudah banyak putusan-putusan pengadilan bahkan putusan setingkat MA yang menjadi tempat penegak hukum menghasilkan keputusan tertinggi sekalipun termasuk dalam kasus kontrak atau perjanjian.

Problema yang kesekian kalinya yang dihadapi oleh konsumen yang menandatangani kontrak konsumen yang umumnya ditawarkan begitu saja oleh pelaku usaha. Misalnya kredit kendaraan bermotor, kredit perbankan, perjanjian sebagai nasabah perbankan, kontrak penitipan barang sebagaimana bermunculannya bentukbentuk aktifitas bisnis yang menggunakan perjanjian baku, yang terjadi di masyarakat dan sudah menjadi fenomena tentang keberadaannya. Bagaimana etikat baik menjadi dasar bagi pihak dalam membuat suatu perjanjian. Untuk menjawab permasalahan ini diperlukan sumber penelitian berupa bahan hukum primer, baik berupa peraturan perundang-undangan, putusan pengadilan dan sumber sekunder berupa buku-buku, teks, kamus-kamus hukum, jurnal hukum. Metode penelitian dalam penulisan ini menggunakan bahan hukum primer dan bahan hukum sekunder, pendekatan undangundang serta pendekatan konseptual. Jenis Penelitian ini adalah Normatif dan bersifat kualitatif.

\section{B. METODE PENELITIAN}

Penelitian yang dilakukan penulis berupa penelitian kualitatif dimana hasil penelitian tidak diperoleh melalui prosedur statistik. Adapun jenis penelitian yang dilakukan berupa studi lapangan, dimana peneliti mengamati dan berpartisipasi secara langsung di lokasi pengambilan data dalam skala kecil atau besar.

${ }^{3}$ Bernard L Tanya dkk, TEORI HUKUM Strategi Tertib Manusia Lintas Ruang dan Generasi, (Yogyakarta, Genta Publishing) 2010, Cet Kedua, hlm 251. 


\section{HASIL TEMUAN DAN PEMBAHASAN}

\section{Pemahaman}

Pemahaman terhadap istilah perjanjian atau kontrak dalam praktek seringkali masih rancu. Sebagian pelaku usaha mencampuradukkan kedua istilah tersebut sebagian memaknai dalam dua istilah yang berbeda. Bila merunut istilah yang digunakan dalam Burgerlijk Wetboek, maka overeenkomst dan contract mempunyai pengertian sama. Istilah tersebut menurut Buku III title Kedua berjudul Tentang "Perikatan-perikatan yang lahir dari Kontrak atau Perjanjian" yang dalam Bahasa aslinya (bahasa Belanda), yaitu "Van verbintenissen die uit contract of overeenkomst geboren worden". Bagian kesatu Ketentuan-ketentuan Umum seharusnya menerangkan tentang pengertian perikatan tapi pada kenyataannya menerangkan tentang dua sumber lahirnya perikatan ${ }^{4}$ Beberapa ahli menggunakan terminologi kontrak disandingkan dengan perjanjian dalam pengertian yang sama diantaranya adalah Jacob Hans Niewenhuis, Hofmann, J Satrio, Soetojo Prawirohamidjojo dan Marthalena Pohan, Mariam Darus Badrulzaman, Purwahid Patrik dan Tirtodiningrat. ${ }^{5}$ Sarjana yang lain beberapa diantaranya menggunakan istilah yang berbeda untuk perjanjian dan kontrak diantaranya adalah Subekti, dengan membedakan kata "perjanjian atau persetujuan" dengan "kontrak", dengan memberikan istilah kontrak mempunyai pengertian lebih sempit karena ditujukan kepada perjanjian atau persetujuan yang tertulis. ${ }^{6}$ Sedangkan makna perjanjian menurutnya suatu peristiwa dimana seorang berjanji kepada seorang lain atau dimana dua orang itu saling berjanji untuk melaksanakan suatu hal. Perikatan menurutnya adalah hubungan hukum antara dua orang atau dua pihak, dimana pihak yang satu berhak menuntut sesuatu hal dari pihak yang lain, dan pihak yang lain berkewajiban untuk memenuhi tuntutan yang dimaksud. ${ }^{7}$ Pothier menyamakan antara kontrak dan perjanjian, tetapi membedakan pengertian dimana dua orang atau lebih menerbitkan, menghapuskan (opheffen), atau mengubah (wijzegen) perikatan. Contract merupakan perjanjian yang mengharapkan terlaksananya perikatan ${ }^{8}$ Telaah kritis tentang penggunaan istilah kontrak atau perjanjian dengan membandingkan antara pengertian kontrak dengan perjanjian yang dianut dalam sistem Anglo-Saxon. Hukum Perikatan atau yang dikenal dalam susunan Buku III Verbintenissenrecht mengatur tentang Overeenkomst yang apabila merujuk ke dalam bahasa Indonesia artinya perjanjian. Kontrak adalah istilah yang diterjemahkan dari bahasa Inggris yaitu contract. Indonesia yang merupakan negara dimana sistem hukumnya Eropa Kontinental pengaturan perjanjian di tempatkan pada Buku III Burgerlijk Wetboek yaitu perikatan, hal ini menandakan bahwa perjanjian berhubungan dengan hal-hal yang disebut harta kekayaan (vermogen). Hal ini serupa dengan contract pada sistem Anglo Saxon. Perjanjian yang dalam bahasa Belanda disebut overeenkomst, istilah Bahasa Inggris adalah agreement

\footnotetext{
${ }^{4}$ Ahmadi Miru \& Sakka Pati, Hukum Perikatan, Cet 7, (Jakarta Rajawali Pers, 2016). Hlm 3

${ }^{5}$ Agus Yudha Hernoko, Hukum Perjanjian Asas Proporsionalitas dalam kontrak komersial, Cet ke-4 (Jakarta Prenadamedia Group, 2014) hlm 13

${ }^{6} \mathrm{R}$ Subekti, Hukum Perjanjian, Cet XVI, (Jakarta, Intermasa) hlm 1

${ }^{7}$ Ibid

hlm 84

${ }^{8}$ Soetojo Prawirohamidjodjo \& Marthalena Pohan, Hukum Perikatan, (Surabaya, Bina Ilmu, 1978)
} 
dimana mengandung pengertian yang luas dari contract, sebab meliputi segala hal yang berhubungan dengan bisnis atau bukan bisnis. Dalam hal agreement yang berkaitan dengan bisnis disebut contract, sedangkan yang tidak berhubungan dengan bisnis dinamakan dengan agreement. Sebagaimana definisi hukum, sampai saat ini belum ada satu definisipun tentang istilah kontrak yang seluruhnya memuaskan. Kesulitannya adalah ketika mendefinisikan kontrak tersebut karena adanya perbedaan terminologi. Tiap-tiap definisi terdapat perbedaan dalam ungkapan yang tepat dan sesuai. Kontrak mempunyai jangkauan sangat luas, mengingat setiap kontrak berakibat suatu janji dan memiliki konsekuensi hukum. Yaitu berupa pelaksanaan janji yang dapat ditegakkan di Pengadilan dengan suatu putusan untuk eksekusi. Unsur janji yang terkandung dalam kontrak menekankan pada penafsiran bahwa kontrak adalah suatu janji atau sekelompok janji. Semisal janji tersebut tidak bisa ditepati, maka hukum yang akan memberikan akibatnya. Kontrak sejatinya terdiri dari banyak elemen-elemen yang beragam. Definisi yang lain tentang kontrak menyebutkan, kontrak adalah perjanjian yang mengikat. Hal ini memiliki ciri khusus karena lebih menitikberatkan pada suatu perjanjian, sebagai salah satu inti dari hukum kontrak. Tetapi masalah muncul ketika faktanya ada bermacam-macam kontrak muncul tanpa suatu perjanjian atau persetujuan ${ }^{9}$ (Quasi Kontrak, Unjust enrichment). Perjanjian juga diatur dalam ajaran keagaman, Islam dalam hal ini dengan Al-Qur'an sebagai kitab suci mengandung aturan-aturan hukum dalam berhubungan dengan sesama manusia yang dikenal dengan istilah mu'amalah. Al-Qur'an mengatur dalam dua istilah yang berhubungan dengan perjanjian. Kata akad (al-'aqdu) secara etimologis yang berarti perjanjian, perikatan atau permufakatan (al-ittifaq) Al-Qur'an memakai istilah ini dalam arti perikatan dan perjanjian. Seperti yang tertulis dalam QS. Al-Maidah ayat $1^{10}$ dan 'ahd (Al-'ahdu) secara etimologis berarti masa, pesan, penyempurnaan serts janji atau perjanjian. Al-Qur'an Surat An-Nahl ayat 91 dan Al-Isra ayat 34. Penggunaan secara umum dalam mu'amalah (transaksi bisnis) adalah akad (al-'Aqd). Kata akad para ahli hukum Islam didefinisikan sebagai: "(Hubungan antara ijab dan Qabul sesuai dengan kehendak syariat yang menetapkan adanya pengaruh (akibat) hukum pada objek perikatan)".

Akad terlihat lebih umum dan memiliki daya ikat kepada para pihak yang melakukan perikatan. Oleh sebab itu akad dapat disamakan dengan istilah perikatan atau verbintenis. ${ }^{11}$ Kata al-'ahdu dapat diartikan sama dengan istilah perjanjian atau overeenkomst. Artinya pernyataan dari seseorang untuk mengerjakan atau tidak mengerjakan sesuatu, dan tidak ada sangkut pautnya dengan kemauan pihak lain. ${ }^{12 J a n j i}$ tersebut terbatas mengikat bagi orang yang bersangkutan, seperti yang diisyaratkan dalam Al-Qur'an Surat Ali Imran ayat 76. ${ }^{13}$

\section{hlm 2}

`John D Calamari, Joseph M Perillo, The Law of Contract, dalam Sri Gambir Melati Hatta II, Op Cit,

${ }^{10}$ Wahbah Zuhaili, “Al-Fiqh al-Islamiy wa Adillatuh”, dalam Fathurrahman Djamil (et-al), Kompilasi Hukum Perikatan, (Bandung, Citra Aditya Bakti, 2016), hlm 247.

${ }^{11}$ Fathurrahman Djamil (et-al), Kompilasi Hukum Perikatan, (Bandung, Citra Aditya Bakti 2016), hlm, 247-248.

${ }^{12}$ Ibid.

${ }^{13}$ Ibid. 
Pemakaian istilah kontrak dan perjanjian, beberapa sarjana memberikan pengertian yang sama antara kontrak dengan perjanjian. Begitu juga secara praktik kedua istilah tersebut digunakan dalam kontrak konsumen, contohnya perjanjian sewa guna usaha, ${ }^{14}$ kontrak pemasangan jaringan internet, kontrak asuransi dsb. Istilah kontrak digunakan juga oleh orang awam dan ahli hukum secara bersama-sama untuk menunjuk suatu dokumen dimana tertulis persyaratan dari suatu kontrak. ${ }^{15}$ Penggunaan kata dimaksud dengan pengertiannya bukan berarti tidak tepat, sepanjang hal tersebut dimaknai secara tegas bahwa aturan-aturan hukum dengan memakai konsep kontrak hampir tidak pernah merujuk kepada tulisannya sendiri. Tetapi sering mengacu kepada persetujuannya sedangkan penulisan terbatas merupakan persetujuan dalam hal pengingat. ${ }^{16}$ Sebagai titik awal perhatian pemaknaan tentang hukum kontrak dimulai dari wilayah atau ruang lingkupnya. Realitasnya kontrak-kontrak yang terjadi di masyarakat mempunyai bentuk dan ukuran yang berbeda. Terdapat kontrak yang melibatkan dana-dana yang besar, atau yang sebaliknya terdapat kontrak dengan skala pendanaan yang kecil. Berkaitan dengan waktu bahwa terdapat sebagian kontrak yang berjangka waktu panjang tetapi sebaliknya terdapat kontrak yang berjangka waktu pendek. Berkaitan dengan isi dari kontrak terdapat bermacam-macam, diantaranya kontrak penjualan, sewa, pekerjaan, kredit, hipotik termasuk perjanjian Leasing dan sebagainya. ${ }^{17}$

Perkembangan kontrak atau perjanjian saat ini dirasakan sangat pesat sebagai konsekuensi logis dari berkembangnya kebutuhan masyarakat yang semakin kompleks akibat perubahan gaya hidup di jaman modern. Para pelaku usaha sebagai pihak penyedia layanan dalam aktifitasnya membuat perjanjian secara tertulis atau perjanjian berbentuk tertulis. Mengingat kontrak atau perjanjian tertulis adalah sebagai dasar para pihak (pelaku bisnis) dalam melakukan penuntutan apabila ada satu pihak yang tidak melaksanakan sesuatu yang di atur dalam kontrak atau perjanjian. ${ }^{18}$ Secara yuridis disamping kontrak yang dibuat secara tertulis, para pihak atau pelaku usaha juga dapat membuat kontrak secara lisan (oral). Tetapi kontrak yang dibentuk demikian ini berresiko sangat tinggi, sebab berpotensi mengalami kesulitan dalam pembuktian apabila terjadi sengketa hukum kontrak di kemudian hari.

Kegiatan bisnis sejatinya selalu didasari aspek hukum bisnis terkait, yang dianalogikan sebagai suatu pesawat udara yang hanya akan dapat terbang dan melaju di udara menuju pendaratan yang menjadi tujuannya jika didukung oleh menara kontrolnya baik di daerah (bandara) keberangkatannya atau daerah (bandara) kedatangannya. ${ }^{19}$ Dalam hal kontrak konsumen seringkali timbul masalah ketika konsumen sadar bahwa telah menyetujui begitu saja kontrak yang disodorkan oleh

\footnotetext{
${ }^{14}$ Keputusan Menteri Keuangan Republik Indonesia, Nomor: 1169 /KMK.1 /1991 tentang Kegiatan Sewa Guna Usaha (Leasing).

${ }^{15}$ Sri Gambir Melati Hatta II, Op Cit, hlm 3.

${ }^{16}$ John D Calamari, Op Cit, hal 3.

${ }^{17}$ Ewan McKendrick, Contract Law dalam Sri Gambir Melati Hatta, Op Cit

${ }^{18}$ Annalisa Yahanan(et.al), Perjanjian Jual Beli Berklausula Perlindungan Hukum Paten, Tunggal Mandiri Publishing, Malang, 2009, hlm. 1.

${ }^{19}$ Muhammad Syaifuddin, HUKUM KONTRAK, Memahami Kontrak dalam Perspektif Filsafat, Teori, Dogmatik dan Praktek Hukum (Seri Pengayaan Hukum Perikatan), Mandar Maju, Bandung, 2012, hlm 1.
} 
pelaku usaha Biasanya kesadaran hukum muncul ketika kontrak yang dilakukan bermasalah. Idealnya pemahaman isi kontrak saat kontrak tersebut dirancang adalah hal yang menjadi syarat mutlak, yang terjadi justru sebaliknya setelah kontrak yang disepakati tersebut bermasalah. Penting untuk dipahami bahwa hampir semua aktifitas bisnis merupakan perbuatan hukum dalam wilayah hukum bisnis, terutama hukum kontrak. Logika hukum bisnis memaknai bahwa dalam dunia bisnis yang mempertemukan para pebisnis dalam aktifitasnya, salah satu hal penting adalah kontrak, dimana kontrak merupakan alat yang penting untuk merangkai hubungan hukum dan mengamankan transaksi bisnis. ${ }^{20}$ Kontrak dimaknai suatu alat pengaman hukum (legal cover) terhadap aktifitas bisnis, baik aktifitas bisnis nasional maupun internasional. ${ }^{21}$ Sebab dalam kontrak terdapat norma-norma hukum (pasal-pasal) konkrit dan individual yang mengatur hak dan kewajiban para pihak. ${ }^{22}$ Sebagai perwujudan dari kehendak (maksud dan tujuan) pihak-pihak yang mengadakan kontrak untuk memperoleh keuntungan (dalam arti luas dan bermakna humanitiskomersial). ${ }^{23}$ Bahwa keuntungan dimaksud mempunyai karakteristik, sebagai berikut: a) mengandung nilai-nilai kemanusiaan, yang mengarahkan aktifitas bisnis sesuai dengan tujuan kodrati manusia yang bertaqwa, berkeadilan, dan berkasih sayang kepada sesama pelaku bisnis dan warga masyarakat secara keseluruhan; b) membolehkan pelaku bisnis mencari keuntungan sebagai laba yang berpijak pada aspek manusia dan kemanusiaan, berwujud materi, digunakan untuk kepentingan pelaku bisnis dan warga masyarakat secara keseluruhan, sebagai refleksi dari tanggung jawab kemanusiaan dan spiritualitas atas laba berdasarkan sifat kasih sayang Tuhan ${ }^{24}$

Perkembangan bentuk-bentuk dan prinsip-prinsip hukum kontrak dipengaruhi oleh tiga faktor, yaitu:

(1) Faktor internal, adalah faktor kebijakan pemerintah untuk memakmurkan negara dan rakyat, sehingga musti turut campur tangan dalam bidang ekonomi, misalnya di Indonesia dikeluarkannya beragam paket deregulasi yang membuka kesempatan berbagai pihak, baik warga negara Indonesia maupun warga negara asing untuk mengembangkan usahanya di Indonesia;

(2) Faktor eksternal, adalah faktor luar negeri dimana menjadikan perekonomian nasional makin terbuka akibat dari desakan arus globalisasi perekonomian dunia, sehingga banyak unsur-unsur asing yang berpengaruh terhadap sistem hukum nasional. Bagi negara Indonesia, realita ini sudah terjadi sejak dibukanya kran bagi investasi asing dan adanya pasar bebas, sehingga tidak ada lagi hambatan dalam berbisnis secara internasional, serta memacu kegiatan kontraktual oleh pemerintah maupun swasta dan makin berkembang prinsipprinsip serta bentuk-bentuk kontrak baru;

${ }^{20}$ Muhammad Syaifuddin, HUKUM KONTRAK, Memahami Kontrak dalam Perspektif Filsafat, Teori, Dogmatik dan Praktek Hukum (Seri Pengayaan Hukum Perikatan), Mandar Maju, Bandung, 2012, hlm 3.

${ }^{21}$ Ibid

${ }^{22}$ Ibid

${ }^{23}$ Ibid

${ }^{24}$ Ibid 
(3) Meningkatnya frekuensi dan aneka macam bentuk kegiatan bisnis, imbasnya intensitas kegiatan pembuatan kontrak juga makin banyak, karena seluruh hubungan yang terjadi selalu dicerminkan ke dalam perjanjian atau kontrak tertulis ${ }^{25}$.

\section{Pentingnya Keabsahan Suatu Perjanjian/Kontrak}

Keabsahan suatu perjanjian/Kontrak mempengaruhi mengikat atau tidaknya perjanjian/kontrak bagi para pembuatnya. Adapun keabsahan perjanjian/kontrak dapat dideteksi menggunakan instrumen hukum dalam bentuk syarat-syarat sahnya suatu perjanjian /kontrak sebagaimana diatur pada Buku III Kitab Undang-Undang Hukum Perdata, yaitu:

1) Pasal 1320 Kitab Undang-Undang Hukum Perdata mengatur syarat sahnya perjanjian/kontrak.

2) Diluar pasal 1320 Kitab Undang-Undang Hukum Perdata, diantaranya: Pasal 1335, 1339, dan Pasal 1347.

Pasal 1320 Kitab Undang-Undang Hukum Perdata adalah instrumen hukum utama untuk menguji sahnya suatu perjanjian/kontrak yang dibuat oleh para pihak, karena pasal tersebut mengatur adanya empat syarat yang harus dipenuhi agar suatu perjanjian/kontrak adalah sah.

(a) Sepakat para pihak dimana saling mengikatkan dirinya (de toestemingvan degenen die zich verbinden);

(b) Kecakapan para pihak saat membuat perjanjian/kontrak (de bekwaamheid om eene verbintenis aan te gaan);

(c) Objek atau pokok persoalan tertentu atau dapat ditentukan (eene bepald onderwerb object);

(d) Sebab atau causa perjanjian tersebut diperbolehkan (eene geoorloofde oorzaak).

Kesepakatan para pihak yang mengikatkan diri atau syarat sahnya suatu perjanjian/kontrak yang pertama, dan kecakapan para pihak yang membuat perjanjian/kontrak merupakan syarat subjektif, sebab berkaitan dengan subjek hukum. Sedangkan objek atau pokok persoalan tertentu atau dapat ditentukan yaitu syarat ketiga dan sebab atau causa yang diperbolehkan yaitu syarat keempat disebut syarat objektif, sebab berkaitan dengan objek hukum yang diperjanjikan.

Kontrak/perjanjian yang tidak terpenuhi syarat-syarat sahnya seperti yang diatur pasal 1320 Kitab Undang-Undang Hukum Perdata apakah syarat subyektif ataupun objektif berpotensi sebagai berikut:

a) Noneksistensi, maksudnya tidak ada kontrak, apabila tidak ada kesepakatan.

${ }^{25}$ Badan Pembinaan Hukum Nasional, Naskah Akademik Kontrak Dagang, Badan Pembinaan Hukum Nasional, Jakarta, hlm 2-4. 
b) Vernietigbaar, bermakna suatu kontrak bisa dibatalkan, apabila kontrak/perjanjian tersebut timbul karena adanya cacat kehendak (wilsgebreke) atau karena ketidakcakapan (onbekwaamheid) (syarat Pasal 1320 Kitab Undangundang Hukum Perdata pertama dan kedua), yang berarti berhubungan dengan tidak terpenuhinya syarat subjektif, berakibat kontrak/perjanjian tersebut dapat dibatalkan; dan

c) Nietig maksudnya kontrak/perjanjian batal demi hukum, jika kontrak/perjanjian tersebut tidak terpenuhi syarat obyektif. ${ }^{26}$

\section{Syarat subyektif terhadap sahnya suatu kontrak/perjanjian.}

Sepakat adalah syarat pertama untuk sahnya suatu kontrak. Kitab UndangUndang Hukum Perdata (KUHPerdata) tidak memberikan penjelasan tentang arti kata sepakat. Pengertian kata sepakat dapat ditemukan dengan merujuk kepada pendapat atau doktrin bahkan teori hukum kontrak yang dikembangkan oleh ahli hukum kontrak. Menurut Herlien Budiono, bahwa "sepakat" mencakup pengertian sepakat untuk mengikatkan diri dan berarti juga sepakat untuk mendapatkan prestasi. Pada kontrak timbal balik, masing-masing pihak mempunyai kewajiban tetapi juga berhak atas prestasi yang telah diperjanjikan. Begitu pula kontrak sepihak yang memuat hak atau kewajiban satu pihak untuk mendapatkan/memberikan prestasi tetap harus ada kata sepakat dari kedua belah pihak. ${ }^{27}$ Sudikno Mertokusuko, menjelaskan kesepakatan sebagai persesuaian pernyataan kehendak antara satu orang atau lebih dengan pihak lainnya. Jadi sesuai dalam hal pernyataannya mengingat kehendak tidak dapat dilihat. Diketahui oleh orang lain. ${ }^{28}$ Pendapat lain disampaikan Annalisa Yahanan, Muhammad Syaifuddin, dan Yunial Laili Mutiari, bahwa sepakat mereka yang mengikatkan diri memiliki tiga arti yaitu:

1) Para pihak pembuat kontrak harus sepakat atau setuju terhadap ha-hal yang pokok. Misalnya: pada kontrak jual beli, dimana harga dan barang adalah hal yang pokok, sedangkan waktu dan tempat penyerahan adalah hal diluar kesepakatan;

2) Hal-hal yang diinginkan pihak yang satu juga diinginkan pihak yang lain, bisa dinyatakan secara tegas (contoh: kontrak sewa menyewa, jual beli), maupun yang diam-diam (kontrak pengangkutan yaitu antara sopir taxi dengan penumpang misalnya sopir mengantar sesuai trayek sedangkan penumpang membayar ongkos);

3) Kebebasan dari para pihak dan tidak ada unsur tekanan yang berakibat adanya cacat dari kebebasan tersebut.

\footnotetext{
hlm 2.

${ }^{27}$ Herlien Budiono, Ajaran Umum Hukum Perjanjian dan Penerapannya di Bidang Kenotariatan, (Bandung, Cutra Aditya Bakti, 2009), hlm 73-74.

${ }^{28}$ Sudikno Mertokusumo, Op Cit, hlm 73-74.
}

26J H Niewenhuis, Pokok-pokok Hukum Perikatan, Terjemahan oleh Djasadin Saragih, Surabaya, 1985, 
Menurut J.H. Niewenhuis kesepakatan dalam kontrak dibentuk oleh dua unsur: pertama, penawaran (aabod, offerte, offer) artinya: sebagai pernyataan kehendak yang mengandung usul untuk menyepakati kontrak, yang meliputi esensialia (unsur yang mutlak harus ada) dalam kontrak yang akan diadakan. kedua: penerimaan (aanvarding, acceptatie, acceptance) yang diartikan: pernyataan setuju dari pihak lain yang ditawari. ${ }^{29}$ dasar keterikatan kontraktual berasal dari pernyataan kehendak dan dibedakan dalam dua unsur, yaitu kehendak (wils) dan pernyataan (verklaring) sehingga dapat diartikan dimana kehendak dan pernyataan adalah syarat terpenting dalam suatu kontrak.

\section{Asas atau Prinsip Dalam Hukum Perjanjian}

Prinsip atau asas hukum adalah dasar dari hukum kontrak. Terdapat prinsip atau asas hukum yang merupakan titik fokus yang dikelompokkan dalam tiga prinsip atau asas utama. Prinsip atau asas utama tersebut yang selanjutnya di anggap soko guru dari hukum kontrak. Sebuah gambaran mengenai latar belakang, cara berfikir yang menjadi landasan hukum kontrak. Sebab sifat fundamental itulah, maka prinsip-prinsip utama dikatakan sebagai prinsip dasar. ${ }^{30}$ Ketiga prinsip tersebut adalah prinsip atau asas konsensualitas, prinsip atau asas kekuatan mengikat suatu kontrak dan prinsip atau asas kebebasan berkontrak. Neuwenhuis menyatakan: asas otonomi, asas kepercayaan dan asas kausa (Drie beginselen van het contracten recht). Norma atau aturan sejatinya memiliki dasar filosofis serta pijakan asas atau prinsip sebagai nyawa. Suatu norma tanpa landasan filosofis serta pijakan asas maka tidak memiliki makna. Pengertian "asas" atau "prinsip" dalam Bahasa Belanda diistilahkan "beginsel" atau "principle". ${ }^{31}$

Asas hukum memiliki peranan yang sangat penting berkaitan dengan kedudukannya pada semua sistem hukum yang didalamnya mengatur sistem norma hukum. Asas hukum adalah fondasi yang menopang kukuhnya suatu norma hukum secara fundamental. Untuk mengetahui hal yang dimaksud dengan asas hukum, beberapa ahli menyampaikan definisi atau pengertian yaitu:

a. Bellefroid, berpendapat bahwa asas hukum umum adalah norma dasar yang diuraikan dari hukum positif, yang oleh ilmu hukum tidak dianggap berasal dari aturan-aturan yang lebih umum. Sehingga asas hukum sejatinya saripati dari hukum yang berlaku pada suatu masyarakat tertentu.

b. Van Eikema Homes, menjabarkan bahwa asas bukan norma hukum yang konkret, melainkan sebagai dasa-dasar umum atau petunjuk-petunjuk bagi hukum yang berlaku. Jadi merupakan dasar atau petunjuk arah dalam pembentukan hukum positif, sehingga dalam pembentukan hukum praktis harus berorientasi pada asas-asas hukum.

c. Paul Scholten, menyebutkan asas hukum adalah pikiran-pikiran dasar, yang terdapat di dalam dan di belakang sistem hukum masing-masing yang

${ }^{29} \mathrm{Op}$ Cit, hlm 2.

${ }^{30}$ Herlien Budiono, Asas Keseimbangan bagi Hukum Perjanjian Indonesia, (Bandung Citra Aditya Bakti, 2015) hlm 64.

${ }^{31} \mathrm{Op}$ cit, hlm 21 
dirumuskan dalam suatu aturan-aturan, perundang-undangan, dan putusanputusan hakim, yang berkenaan dengan ketentuan-ketentuan dan keputusankeputusan individual dapat dipandang sebagai penjabarannya ${ }^{32}$

Kedudukan asas hukum adalah pondasi norma hukum pada dasarnya memberikan arah, tujuan serta penilaian dasar bagi eksistensi dari suatu norma hukum. Bahkan beberapa ahli mengemukakan makna asas hukum merupakan jantung atau hatinya norma hukum (peraturan hukum). Menurut GW Paton ${ }^{33}$ hal ini didasari oleh 2 alasan yaitu:

a. Asas hukum merupakan "landasan" yang terluas bagi terbentuknya suatu norma hukum. Sehingga setiap norma hukum pada gilirannya dapat dikembalikan pada asas hukum- asas hukum tersebut.

b. Asas hukum merupakan "alasan" bagi timbulnya suatu norma hukum atau merupakan "ratio legis" norma hukum. Hendak terus melahirkan norma hukum. Asas hukum tidak akan habis kekuatannya dengan menciptakan norma hukum, tetapi tetap eksis dan akan terus menciptakan norma hukum-norma hukum baru.

Selanjutnya dikatakan Satjipto Rahardjo asas hukum berguna sebagai pondasi yang memberikan arah, tujuan serta penilaian dasar, mengandung nilai-nilai, dan tuntutan etis. Berkaitan dengan hal ini menurut Bachsan Mustafa, sistem, asas, norma dan tujuan hukum bermanfaat sebagai pedoman dan ukuran atau kriteria bagi perilaku manusia. ${ }^{34}$ Asas-asas hukum bukan hanya berfungsi untuk memecahkan masalahmasalah baru dan membuka bidang baru, tetapi juga diperuntukkan dalam menafsirkan aturan-aturan sejalan dengan asas-asas yang mendasariaturan-aturan dimaksud. ${ }^{35} \mathrm{Asas}$ hukum dapat menjadi jembatan dari norma hukum merubah sifatnya menjadi bagian suatu tatanan etis yang selaras terhadap nilai- nilai kemasyarakatan. Penafsiran terhadap suatu norma hukum termasuk pertanyaan mengenai mengapa norma hukum perlu diundangkan dapat dirunut dari "ratio leges" tersebut. Selanjutnya Satjipto Rahardjo menambahkan walaupun asas hukum bukan norma hukum tetapi tidak ada norma hukum yang dapat dipahami tanpa mengetahui asas-asas hukum yang terdapat di dalamnya. ${ }^{36}$ Perbedaan antara peraturan hukum dengan asas hukum adalah berkaitan dengan penerapannya bahwa peraturan hukum yang kongkret dapat diterapkan dengan cara langsung terhadap peristiwanya sedangkan asas hukum penerapannya dengan cara tidak langsung. Sebagai cara untuk menemukan asas hukum umum maka digali sifat-sifat umum dalam norma yang konkrit, atau menggali kesamaan-kesamaan yang terdapat dalam peraturan yang dimaksud. Tanda-tanda dari sifat asas hukum yang mengakui kemungkinan-kemungkinan (tidak tetap) berakibat

${ }^{32} \mathrm{Op}$ Cit, hlm 22

${ }^{33}$ Satjipto Raharjo, Ilmu Hukum, (Bandung, Citra Aditya Bakti, 2000) hlm 45

${ }^{34}$ Bachsan Mustafa, Sistem Hukum Indonesia Terpadu, (Bandung, Citra Aditya Bakti, 2003) hlm 49.

${ }^{35}$ Bruggink J.J.H," Rechtsrefflecties, Grondbegrien uit de rechtstheorie" dalam Herlien Budiono, Asas Keseimbangan bagi Hukum Perjanjian Indonesia, Hukum Perjanjian Asas-asas Wigati Indonesia, (Bandung, Citra Aditya Bakti, 2015) hlm 306.

${ }^{36} \mathrm{Op}$ Cit, hlm 47. 
sistem hukum menjadi luwes. ${ }^{37}$ Asas Hukum umumnya berubah seiring mengikuti norma hukumnya. Norma hukum pada gilirannya akan berubah mengikuti perkembangan masyarakat. Dalam hal ini dipengaruhi dimensi ruang atau tempat dan waktu. Asas hukum juga mengenal bersifat umum (berhubungan dengan semua bidang hukum, misal asas lex specialis derogate leg generalis) dan ada pula yang bersifat khusus (berhubungan dengan bidang hukum tertentu contoh asas konsensualisme di bidang hukum perdata). Prinsip hukum umum dipandang sebagai suatu sumber hukum penting untuk upaya pengembangan hukum. ${ }^{38}$ Asas-asas hukum yang merupakan tiang penyangga hukum kontrak adalah asas kebebasan berkontrak berdiri sejajar dengan asas-asas hukum lain berdasar kadar yang berimbang, diantaranya: 1). Asas pacta sunt servanda; 2). Asas kesederajatan; 3). Asas profity of contract; 4). Asas konsensualisme; dan 5). Asas itikad baik. ${ }^{39}$

\section{KESIMPULAN}

Asas etikat Baik selayaknya menjadi roh dalam setiap perjanjian tanpa menerapkan asas etikat baik maka melanggar umumnya kaidah-kaidah dari Buku III KUHPerdata khususnya, asas kebebasan berkontrak dilanggar termasuk melanggar undang-undang perlindungan konsumen, sehingga membuka peluang terjadi pelaksanaan kebebasan berkontrak yang tidak seimbang dan tidak memperhatikan perlindungan konsumen dan rasa keadilan masyarakat. Prinsip-prinsip yang termuat dalam perjanjian konsumen harus memiliki keselarasan dengan prinsip-prinsip perikatan yang baik dalam hukum perjanjian, agar tercapai apa yang menjadi tujuan pembuatan perjanjian yaitu melindungi kepentingan kedua belah pihak secara seimbang demi tercapainya keadilan. Mengedepankan asas kebebasan berkontrak dan asas kesepakatan serta mengabaikan asas keseimbangan atau asas perlindungan akan menimbulkan persoalan hukum.

Saran:

Itikad baik harus menjadi roh perjanjian baik pada saat pra kontrak, kontrak berlangsung maupun sesudah kontrak sehingga akan menghasilkan perjanjian yang adil dan tidak menimbulkan sengketa dikemudian hari.

\section{Referensi:}

\section{Buku Dan Jurnal}

Budiono, Herlien. Ajaran Umum Hukum Perjanjian dan Penerapannya di Bidang Kenotariatan, (Bandung, Citra Aditya Bakti, 2009)

\footnotetext{
${ }^{37} \mathrm{Op}$ Cit hlm 35.

38Salim HS, Hukum Kontrak Teori Dan Teknik Penyusunan Kontrak, (Jakarta, Sinar Grafika, 2010).

${ }^{39} \mathrm{M}$ Isnaeni, "Hukum Perikatan dalam Era Perdagangan Bebas" dalam Muhammad Syaifuddin, Op Cit, hlm 75.
} 
Budiono, Herlien. Asas Keseimbangan bagi Hukum Perjanjian Indonesia, Hukum Perjanjian Asas-asas Wigati Indonesia, (Bandung, Citra Aditya Bakti, 2015).

Djamil, Fathurrahman. (et-al), Kompilasi Hukum Perikatan, (Bandung, Citra Aditya Bakti 2016)

Hatta, Sri Gambir Melati. Peranan Itikad Baik Dalam Hukum Kontrak Dan Perkembangannya, Serta Implikasinya Terhadap Hukum Dan Keadilan (Pidato), Jakarta, 2000)

Hernoko, Agus Yudha. Hukum Perjanjian Asas Proporsionalitas dalam kontrak komersial, Cet ke-4 (Jakarta, Prenadamedia Group, 2014)

Miru, Ahmadi. \& Sakka Pati, Hukum Perikatan, Cet 7, (Jakarta Rajawali Pers, 2016)

Mustafa, Bachsan. Sistem Hukum Indonesia Terpadu, (Bandung, Citra Aditya Bakti, 2013)

Niewenhuis, J H. Pokok-pokok Hukum Perikatan, Terjemahan oleh Djasadin Saragih, Surabaya, 1985)

Prawirohamidjodjo, Soetojo; \& Marthalena Pohan, Hukum Perikatan, (Surabaya, Bina Ilmu, 1978)

Raharjo, Satjipto. Ilmu Hukum (Bandung, Citra Aditya Bakti, 2000)

Runtung, Cherdina Efenti; Bismar Nasution, Makmul Siregar, Kecenderungan Putusan-putusan Hakim Pengadilan Terhadap Pencantuman Klausula Eksonerasi dalam Perjanjian, USU Law Journal, Vol 3 No. 2 (Agustus 2015)

Salim HS, Hukum Kontrak Teori Dan Teknik Penyusunan Kontrak, (Jakarta, Sinar Grafika, 2010)

Subekti, R. Hukum Perjanjian, Cet XVI, (Jakarta, Intermasa)

Syaifuddin, Muhammad. HUKUM KONTRAK, Memahami Kontrak dalam Perspektif Filsafat, Teori, Dogmatik dan Praktek Hukum (Seri Pengayaan Hukum Perikatan), (Bandung, Mandar Maju, Bandung, 2012)

Tanya, Bernard L. dkk, TEORI HUKUM Strategi Tertib Manusia Lintas Ruang dan Generasi, Cet Kedua (Yogyakarta, Genta Publishing, 2010).

Yahanan, Annalisa. (et.al), Perjanjian Jual Beli Berklausula Perlindungan Hukum Paten, Malang, Tunggal Mandiri Publishing, 2009)

\section{Peraturan Perundang-Undangan:}

Undang-undang Dasar Negara Republik Indonesia 1945

Kitab Undang-undang Hukum Dagang

Kitab Undang-undang Hukum Perdata

Undang-undang Nomor 8 Tahun 1999 Tentang Perlindungan Konsumen 